\title{
Pigmented basal cell carcinoma: a rare variant at a rare site
}

\author{
Ravindranath B. Chavan*, Anil P. Gosavi, Megha V. Kakani, Swaraj D. Potdar, Atika Agrawal
}

Department of Dermatology, Venereology and Leprosy, BJ GMC, Sassoon General Hospitals, Pune, Maharashtra, India

Received: 17 December 2019

Revised: 07 March 2020

Accepted: 09 March 2020

\section{*Correspondence:}

Dr. Ravindranath B. Chavan,

E-mail: drravindranathchavan@gmail.com

Copyright: (C) the author(s), publisher and licensee Medip Academy. This is an open-access article distributed under the terms of the Creative Commons Attribution Non-Commercial License, which permits unrestricted non-commercial use, distribution, and reproduction in any medium, provided the original work is properly cited.

\begin{abstract}
Basal cell carcinoma (BCC), is a most common malignancy reported in the western world. It arises most often in sunexposed areas (80-85\%) especially head and neck consistent with the etiologic role of solar radiation. However, there are atypical localizations such as abdomen, perianal region, groin that require a higher index of suspicion to arrive at the correct diagnosis. Exposure to sunlight is thought to be most responsible etiological factor of BCC, although trauma and scar tissue have also been implicated as possible etiological causes. It has a cure rate of $100 \%$ with early diagnosis and surgical excision. Pigmented BCC is a rare clinical and histological variant of BCC that exhibits increase pigmentation. We present a case of rare variant of basal cell carcinoma of abdominal location over a prior surgical scar.
\end{abstract}

Keywords: Basal cell carcinoma, Surgical scar, Hyper pigmented tumour, Melanocytes

\section{INTRODUCTION}

Basal cell carcinoma (BCC) is the most common cutaneous malignancy, representing around $65 \%$ of the epithelial tumors. ${ }^{1}$ It is more prevalent after the fourth decade of life, and its peak incidence is at the sixth decade of life in both sexes. It presents local invasion, has low metastasizing potential and a cure rate of $100 \%$ after surgical excision. BCC generally occurs in adults, predominantly on the head and neck, followed by the trunk. Rare sites include genitalia, perianal skin and extremities. $^{2}$

The risk factors for BCC include phenotypic characteristics of the patients, such as light skin and eye color; environmental risks, especially ultraviolet B radiation; previous exposure to arsenic; radiotherapy and genetic syndromes, such as xeroderma pigmentosum and basal cell nevus syndrome. ${ }^{3}$
Pigmented BCC (PBCC) is a rare variant with few cases described in English literature. ${ }^{4}$ A correlation between skin trauma, scar and carcinogenesis have also been suggested as playing role in skin cancer pathogenesis. An association between BCC and scar tissue has been noted in several reports. The most common scar types associated with BCC are previous vaccinations and small pox scars while burn scars are also associated with fewer. ${ }^{5-12}$ Only few cases arising from surgical scars have been reported in the literatures we reviewed. ${ }^{10-12}$

\section{CASE REPORT}

A 54 years old female, resident of Maharashtra, housewife by occupation, presented to our outpatient department with complaints of painless verrucous growth over the lower abdomen with no associated complaints which patient started noticing since 1year, initially started as small raised pea sized lesion which gradually progressed over a period of 6months to the present size. 
There was a previous history of operation of tubal ligation done at the same site 30 years back. The outcome of operation was uneventful and the lesion had been present 29 years after that operation.

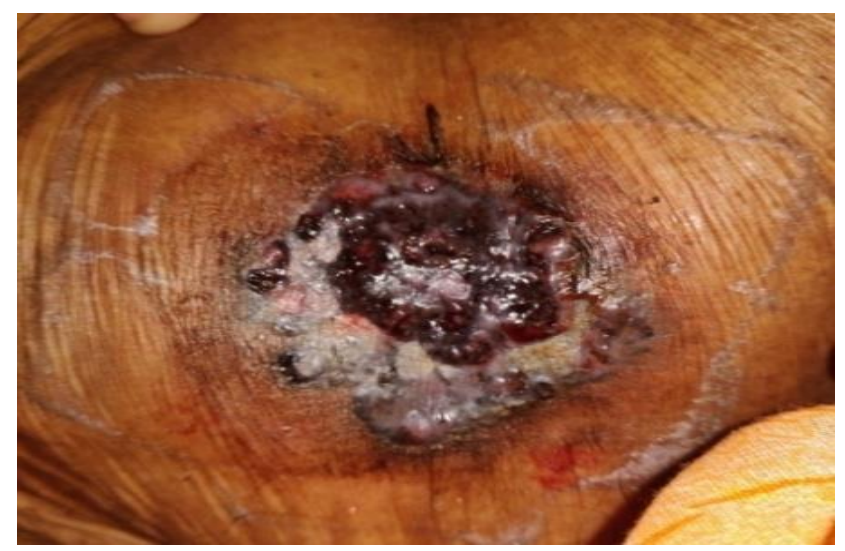

Figure 1: Well defined hyper pigmented ulcerated tumor of approximately $7 \times 7 \mathrm{~cm}$, with hyper pigmented raised beaded border, hemorrhagic crusting and minimal serosanguinous discharge.

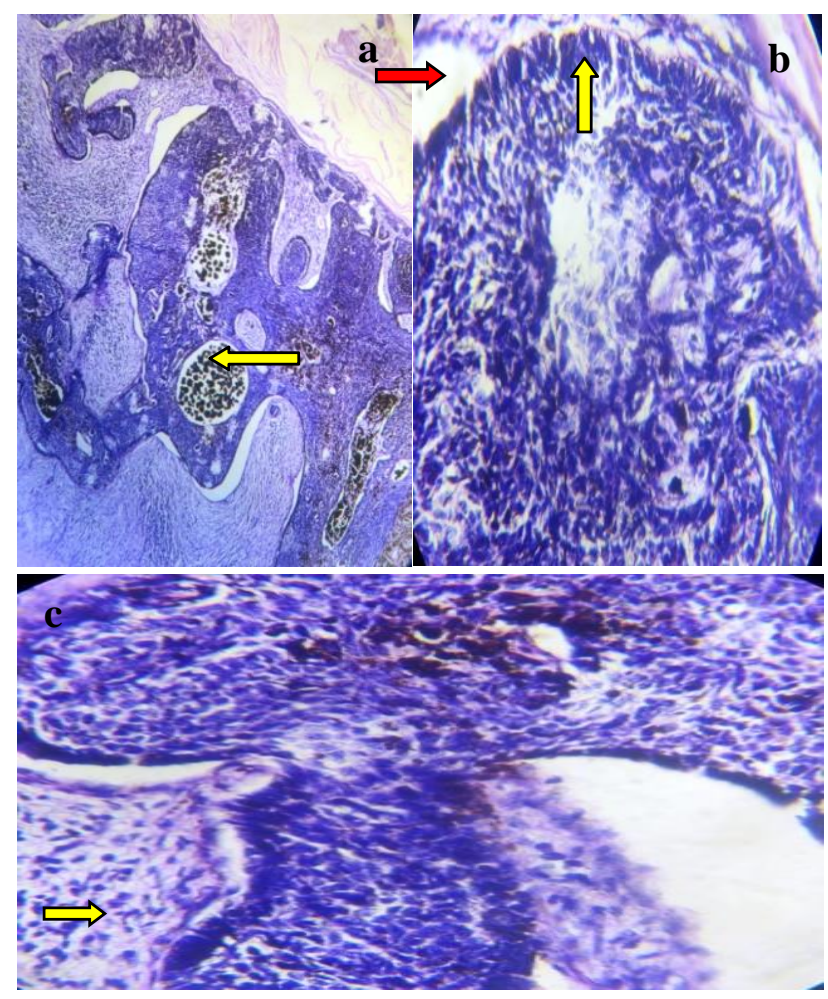

Figure 2: (a) 10X view: multiple islands of pigmented tumor cells (yellow arrow), (b) $40 \mathrm{X}$ view: tumor cells having basophilic nuclei with abundant melanin pigment (green arrow), peripheral palisading of cells (yellow arrow) and peripheral clefting (red arrow), and (c) 40X view: deeper tissue showing adnexal structure with fibro collagenous tissue and mild periadnexal and perivascular lymphoplasmacytic infiltrates (yellow arrow).
On physical examination she presented a well-defined hyper pigmented ulcerated tumor of approximately 7 by 7 $\mathrm{cm}$, with hyper pigmented raised beaded border, hemorrhagic crusting over floor and non-tender non indurated base with minimal serosanguinous discharge, without any other alterations in the surrounding skin (Figure 1).

Provisional diagnosis of Bowens disease, secondary infected porokeratosis basal cell carcinoma and squamous cell carcinoma was made. A punch biopsy was performed in the vicinity of the border which showed tumor tissue arising from basal layer arranged in sheets, lobules and nest. Individual tumor cells had basophilic nuclei with abundant melanin pigment. Tumor cells were having peripheral clefting. Deeper tissue showed adnexal structure with fibro collagenous tissue and mild periadnexal and perivascular lymphoplasmacytic infiltrate (Figure 2). With these histopathological findings, we established a diagnosis of BCC arising on a surgical scar. Subsequently the patient was referred to plastic surgery for total excision of the lesion.

\section{DISCUSSION}

$\mathrm{BCC}$ is the most common skin cancer with a predilection for chronically sun-exposed areas, mainly the face and neck, and is most frequently seen in adults aged 40 years or older.

The existence of BCCs in non-sun-exposed areas is rare and suggests the existence new, currently unknown, etiologic factors. Approximately $80-85 \%$ of BCC documented in medical literature are located on the head or neck, $15 \%$ on the trunk and less than $2 \%$ in areas considered unusual such as abdomen, genitals, perianal skin, lateral edge of the foot, axilla, superior or inferior lip. ${ }^{13}$

Among all variant of $\mathrm{BCC}$, pigmented $\mathrm{BCC}$ variety is about $6 \%$ and histo-pathologically it is similar to nodular BCC with increased melanisation. ${ }^{14}$

In a review of 2126 cases of BCC in 1979, Rabbari and Mehregan recorded the anatomical location of each lesion and reported that $82.92 \%$ were situated on the head or neck, $9.84 \%$ on the trunk, $6.76 \%$ on the limbs and $0.48 \%$ in the genitals or perianal region. ${ }^{15}$

In another review of 873 cases of BCC in Argentina in 2010, Abeldano et al, established the proportion of BCCs in different anatomical regions. ${ }^{16}$ The results showed that $65.4 \%$ occurred in the head or neck, of which $59.1 \%$ were located solely on the face. Less than $2 \%$ of lesions appeared in infrequent locations, such as abdomen, perianal region, groin, among others.

The main etiologic factor in the development of BCC is ultraviolet radiation, however, considering the occurrence of lesions in non-sun-exposed areas, the existence of 
other contributing factors has been proposed. These include: immunosuppression, Fitzpatrick skin type (phototype) I-II-III, ionizing radiation, genodermatoses, nevus sebaceous and arsenic exposure.

Trauma and scar tissue have also been associated with the development of BCC, and the period between the onset of trauma and tumor formation can range from weeks to decades. ${ }^{17-19}$ The aetiology of the apparent association between trauma and BCC may be related to inflammation and growth factors involved in wound healing, a lack of immunological mechanisms in scars creating an environment interfering with the immune surveillance has been theorized, and it has been suggested that depressed cellular immunity could play a role in carcinoma development in scars. ${ }^{20,21}$ The malignancy resulting from scars are frequently squamous cell carcinoma, but BCC, carcinosarcoma, adenoacanthoma, and malignant melanoma and sarcoma developing on these unstable scars have been already reported. ${ }^{17,22,23}$

Nodular basal cell carcinoma is the most common variety of basal cell carcinoma. It begins as a small, slightly elevated papule with central depression. Pigmented basal cell carcinoma in addition to features seen in lesions of nodular BCC, contains increased brown or black pigment. Our case too showed all the features of a BCC along with increased pigmentation. Cystic BCC lesions are translucent blue-grey cystic nodules that may mimic benign cystic lesions. Superficial BCC presents as scaly patches or papules that are pink to red-brown in color often with central clearing. Superficial BCC is often found on the trunk and extremities, although $40 \%$ still occurs on the head and neck. ${ }^{24}$ Micro-nodular BCC appears as yellow-white when stretched, whereas morphea form and infiltrating basal cell carcinoma present as sclerotic plaques or papules. Ulceration, bleeding and crusting are uncommon. Both micronodular and morphea form subtypes are aggressive in nature.

The mainstay of treatment remains the wide local excision with at least $2 \mathrm{~cm}$ margins. ${ }^{25-28}$ Alternatively, Mohs micrographic surgery can be considered. Radiation therapy often follows excision as an adjuvant therapy, depending on the type of tumor. ${ }^{26,28}$ The prognosis of the cutaneous malignancies in this setting depends on several factors including location, type of malignancy, immune status, progression of disease, and lymph node metastasis. Our patient's presentation with a BCC should carry a good overall prognosis, though she will need to be closely followed for recurrence after wide local excision.

\section{CONCLUSION}

This novel presentation of rare variant of BCC i.e., pigmented BCC in a surgical scar at an unusual site may serve as a reminder to consider this diagnosis and biopsy in a non-healing ulcer within any type of chronic wound or scar.

\section{ACKNOWLEDGEMENTS}

The authors are thankful to the department of pathology, B. J. government medical college and Sassoon general hospital, Pune for their contribution in the diagnosis of the case.

\section{Funding: No funding sources \\ Conflict of interest: None declared \\ Ethical approval: Not required}

\section{REFERENCES}

1. Betti R, Inselvini E, Carducci M, Crosti C. Age and site prevalence of histologic subtypes of Basal cell carcinomas. Int J Dermatol. 1995;34:174-6.

2. Newman JC, Leffell DJ. Correlation of embryonic fusion planes with the anatomical distribution of basal cell carcinoma. Dermatol Surg. 2007;33:957-65.

3. Zuuren EV, Bastiaens MT, Posma AN, Bavinckt JNB. Basal cell carcinoma on the dorsum of the hand: report of 11 cases. J Eur Acad Dermatol Venereol. 2000;14:307-10

4. Kanitakis J, Vidal AE, Faure M. Extensive pigmented vulvar basal-cell carcinoma presenting as pruritus in an elderly woman. Dermatol Online J. 2011;17:8.

5. Castrow FF, Williams TE. Basal cell epithelioma occurring in a smallpox vaccination scar. J Dermatol Surg. 1976;2:151.

6. Goncalves JCA. Malignant change in smallpox vaccination scars. Arch Dermatol. 1966;93:229.

7. Zelickson AS. Basal cell epithelioma at site and following smallpox vaccination. Arch Dermatol. 1968;98:35.

8. Riley KA. Basal cell epithelioma in smallpox vaccination scar. Arch Dermatol. 1970;101:416.

9. Gordon HH. Complications of smallpox vaccination: basal cell carcinoma, keloids, acute bullous reaction. Cutis. 1974;13:444.

10. Warren GH, Pearlmen NW, Cain TL. Carcinoma arising in a tracheostomy scar. Arch Otolaryngol. 1983;109:352-3.

11. White JW. Basal cell carcinoma in a hair transplantation recipient site. Cutis. 1979;23:322-5.

12. Jorquero E, Moreno JC, Diaz Cano SJ. Basal cell carcinoma arising in a surgical scar: reconstructive surgical treatment. J Dermatol Surg Oncol. 1994;20:846-7.

13. Fabio DN, Feinsilber DG, Cha DM. Basal cell carcinoma: unusual sites. Rev Argent Dermatol. 1986;67:135-8.

14. Freedberg IM, Eisen AZ, Wolff K, Austin KF, Goldsmith IA, Katz SI. Fitzpatrick's and dermatology in general medicine. 6th edition, McGraw-Hill, New York; 2003.

15. Rahabari H, Mehregan AH. Basal cell epitheliomas in usual and unusual sites. $\mathrm{J}$ Cut Pathol. 1979;6(5):425-31. 
16. Abeldano. Basal cell carcinomas of unusual locations. Rev Argent Dermatol. 2010;16:25-33.

17. Noodleman FR, Pollac SV. Trauma as a possible etiologic factor in basal cell carcinoma. J Dermatol Surg Oncol. 1986;12:841-6.

18. Ozyazgan I, Kontaş O. Previous injuries or scars as risk factors for the development of basal cell carcinoma. Scand J Plast Reconstr Surg Hand Surg. 2004;38:11-15.

19. Lim KR, Cho KH, Hwang SM, Jung YH, Song JK. Basal cell carcinoma presenting as a hypertrophic scar. Arch Plast Surg. 2013;40:289-91.

20. Bostwick J, Pendergrast WJ, Vasconez LO. Marjolin's ulcer: an immunologically privileged tumor. Plast Reconstr Surg. 1976;57:66-9.

21. Dellon AL, Potvin C, Chretin PB, Rogentine CN. The immunobiology of skin cancer. Plast Reconstr Surg. 1975;55:341-54.

22. Horton CE, Crawford HH, Love HG, Loeffler RA. The malignant potential of burn scar. Plast Reconstr Surg Transplant Bull. 1958;22(4):348-53.

23. Giblin T, Pickrell K, Pitss W, Armstrong D. Malignant degeneration in burn scars. Ann Surg. 1965;162:291.
24. Nakayama M, Tabuchi K, Nakamura Y, Hara A. Basal cell carcinoma of the head and neck. J Skin Cancer. 2011;1-9.

25. Daya M, Balakrishan T. Advanced Marjolin's ulcer of the scalp in a 13-year-old boy treated by excision and free tissue transfer: case report and review of literature. Indian J Plast Surg. 2009;42:106-11.

26. Pavlovic S, Wiley E, Guzman G. Marjolin ulcer: an overlooked entity. Int Wound J. 2011;8:419-24.

27. Asuquo M, Ugare G, Ebughe G. Marjolin's ulcer: the importance of surgical management of chronic cutaneous ulcers. Int J Dermatol. 2007;46(2):29-32.

28. Aydogdu E, Yildirim S, Akoz T. Is surgery an effective and adequate treatment in advanced Marjolin's ulcer. Burns. 2005;31:421-31.

Cite this article as: Chavan RB, Gosavi AP, Kakani MV, Potdar SD, Agrawal A. Pigmented basal cell carcinoma: a rare variant at a rare site. Int J Res Dermatol 2020;6:416-9. 